Ann. Biol. anim. Bioch. Biophys., 1977, 17 (2), 147-152.

\title{
Serum proteins in magnesium-deficient rat
}

\author{
par Y. RAYSSIGUIER ( $\left.{ }^{(}\right)$, P. LARVOR ( $\left.{ }^{1}\right)$, Y. AUGUSTI ( $\left.{ }^{2}\right)$ and J. DURLACH $\left({ }^{3}\right)$
}

(1) Station de Physiopathologie de la Nutrition, I. N. R. A., Theix, Saint Genes Champanelle, 63110 Beaumont, France

(2) Institut Prophylactique, Paris

(3) Centre de Recherches sur le Métabolisme Magnésique, Hôpital Cochin, Paris

Summary. Hypoproteinemia appears early in the magnesium-deficient rat with a drop in serum albumin after two days of depletion. This is not due to urinary loss but more probably to defective protein synthesis. A drop in $\gamma$ globulins is observed after 10 days of depletion ; this drop becomes more marked. A transitory increase in seromucoid is probably related to inflammatory phenomena.

\section{Introduction.}

In the magnesium-deficient rat, we have shown serum protein modifications related to immunologic and allergic disorders (Augusti et al., 1973). The relation of magnesium to the immune status and to inflammatory processes is of great biological significance. Magnesium depletion seems to decrease resistance to infection and also cause a non-specific inflammatory state, but this subject is not well documented (Pechery et al., 1971).

Plasma magnesium levels drop very early during magnesium deficiency and lesions, as nephrocalcinosis, quickly appear (Rayssiguier and Larvor, 1974). This induced us to study the time course of plasma protein concentration in magnesiumdeficient rats.

\section{Material and methods.}

Seventy male Sherman rats initially weighing $180 \mathrm{~g}$ were fed a semi-synthetic diet (table 1).

Thirty-five rats were fed this diet ad libitum without magnesium added (30 ppm of $\mathrm{Mg}$ ), and 35 control rats were pair-fed the same ration with magnesium added (1500 ppm of Mg) ; 5 control and 5 deficient rats were bled by cardiac puncture under slight ether anesthesia and then killed at days 2, 4, 7, 10, 14, 21 and 28. 


\section{Results.}

1) Clinical and biochemical signs of magnesium deficiency were observed. Hypomagnesemia appeared early; on the second day of treatment, plasma $\mathrm{Mg}$ was $1.65 \pm 0.03$ and $0.75 \pm 0.02 \mathrm{mg} / 100 \mathrm{ml}$ in control and deficient animals, respectively. Ear hyperemia appeared in $\mathrm{Mg}$-deficient rats after 4 to 7 days, then disappeared in 3 to 10 days; there was hyperexcitability after 7 days. The deficient animals lost weight even when compared to pair-fed controls.

2) Total proteins : hypoproteinemia was significant since day 4 , and increased progressively during the deficiency (fig. 1).

3) Albumins : albumins dropped early, showing a significant decrease after 2 days (fig. 1 ).

4) Alpha globulins : $\alpha_{1}$ and $\alpha_{2}$ globulins did not change significantly, except for a drop on day 10. $\alpha_{3}$ globulins showed a slight but sustained increase (fig. 2 ).

5) Beta globulins : $\beta$ globulins were not significantly altered (fig. 2 ). (fig. 2).

6) Gamma globulins : decrease was progressive and significant after 10 days

7) Seromucoid : transitory increase was significant at days 10 and 14 (fig. 3).

8) Urine proteins : there was no proteinuria except for a few erratic cases in control as well as in deficient rats.

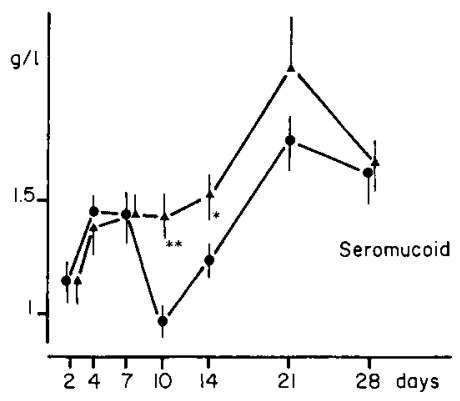

FIG. 3. - Seromucoid in magnesium deficient ( $\mathbf{\Delta}$ ) and control (e) rats.

The same expression of results as in fig. 1 and 2 .

\section{Discussion.}

The effects of magnesium deficiency on serum proteins are in agreement with previous results : hypoproteinemia (Greenberg, Lucia and Tufts, 1938 ; Ko, Fellers and Craig, 1962 ; Bunce et al., 1963 ; Schwartz, Wang and Woodcock, 1969 ; Elin, Armstrong and Singer, 1970 ; Augusti ef al., 1973) with a striking drop in albumin (Schwartz, Wang and Woodcock, 1969 ; Augusti et al., 1973), slight, variable effects on $\alpha$ and $\beta$ globulins, and decrease in $\gamma$ globulins (Elin, Armstrong and Singer, 1970 ; Augusti et al., 1973). The early and progressive drop in total serum proteins seems to be a combination of very early albumin decrease and progressive $\gamma$ globulin decrease. 
It may be related to disturbances in protein synthesis because no proteinuria was found as in previous experiments (Cantin, 1973).

Decrease in serum albumin synthesis has already been demonstrated (Schwartz ef al., 1970).

The proteinuria observed in a few cases in normal rats is a common finding previously described in detail (Berg, 1965).

There are many implications to the decrease of protein synthesis during magnesium deficiency. Impaired growth is constantly found in magnesium-deficient animals ; vascular calcifications are related to decreased elastine synthesis (Britton and Stokstad, 1970). Hypoproteinemia and hypotension may induce modification of aldosterone secretion (Ginn et al., 1967 ; Merlino-Solounias and Schwartz, 1976) through alteration of the juxiaglomerular granulation status (Cantin, 1973).

The drop in the $\gamma$ globulin levels may represent an immunologic consequence of decreased protein synthesis. $\gamma$ globulins diminish progressively and concomitantly with a decrease in $\mathrm{lg} G$ which appears after two weeks of magnesium deficiency (Alcock and Shils, 1974). The magnesium supplementation increases Ig $\mathrm{G}$ in $\mathrm{Mg}$-deficient rats. Impairment of the production of circulating antibodies has been studied : antibody level against Salmonella pullorum is lower in chronically magnesium-deficient piglets (Miller et al., 1963). The titers of agglutinins and hemolysins against sheep red blood cells are decreased in magnesium-deficient rats (Battifora, 1971; McCoy and Kenny, 1975).

Mg deficiency in mice can cause considerable depressed immune response by reducing the number of antibody-secreting cells (Elin, 1975). In contrast to these results, mouse circulating lgE response to ovalbumin injection is increased in magnesium-deficient animals (Prouvost-Danon et al., 1975); in spite of impaired production of circulating antibodies and cell-mediated immunity, thymic and lymphoid hyperplasia was reported in magnesium-deficient animals (Jasmin, 1963).

Acute magnesium deficiency in rat is characterized by ear hyperemia, disappearing rapidly after some days. The transitory increase in seromucoid may be related to this short inflammatory state accompanied by an increase in plasma and urinary histamine levels (Bois, Gascon and Beaulnes, 1963).

In conclusion, magnesium deficiency induces early modifications in serum protein levels ; some of these (hypoalbuminemia) are apparently a direct consequence of the role played by magnesium in protein synthesis. Other changes may be mainly related to magnesium participation in the maturation and multiplication of antibody-producing cells (hypogammaglobulinemia) or may result from inflammatory processess (increased seromucoid levels).

Accepté en seplembre 1976.

Résumé. Des rats mâles de souche Sherman pesant au départ $180 \mathrm{~g}$ ont été nourris en alimentation appariée avec une ration semi-synthétique carencée en $\mathrm{Mg}(30 \mathrm{mg} / \mathrm{kg})$ ou complémentée en cet élément ( $1500 \mathrm{mg} / \mathrm{kg}$ ). Cinq témoins et 5 carencés ont été sacrifiés au temps $2,4,7,10,14,21$ ou 28 jours. Pendant la dernière journée avant le sacrifice, les rats étaient placés en cages métaboliques individuelles et les urines de 24 heures récoltées. Les signes classiques du déficit magnésique ont été observés : hypomagnésémie significative dès le $2^{\mathrm{e}}$ jour, hyperémie des territoires cutanés, perte de poids des carencés par rap- 
port aux témoins en dépit de l'alimentation appariée ef hyperexcitabilité. Les protéines sériques ont été modifiées de la façon suivante :

L'hypoprotéinémie est significative dès le $4 \mathrm{e}$ jour et persiste pendant toute la durée de la carence. Les albumines baissent très précocement 48 heures après le début de l'alimentation carencée. Les modifications des $\alpha_{1}, \alpha_{2}$ ef $\beta$ globulines sont plus discrètes et caractérisées par une baisse transitoire des $\alpha_{1}, \alpha_{2}$ globulines. Les $\alpha_{3}$ globulines augmentent tardivement. La baisse des $\gamma$ globulines est progressive à partir du $10^{\mathrm{e}}$ jour de carence. II y a une augmentation transitoire du séromucoïde. Il n'y a pas de protéinurie et l'hypoprotéinémie n'est pas due à des perturbations dans l'excrétion urinaire mais pourrait être en rapport avec une diminution de la synthèse protéique. Il faut souligner la précocité de la baisse des protéines sanguines en cas de déficit magnésique. La baisse des $\gamma$ globulines est à mettre en rapport avec le rôle du magnésium dans les processus immunitaires de défense de l'organisme. L'élévation du séromucoïde traduit un éłat inflammatoire lié au déficit magnésique.

\section{References}

ALCOCK N. W., SHILS M. E., 1974. Serum immunoglobulin $G$ in the magnesium-depleted rat. Proc. Soc. Exp. Biol. Med., 145, 855-858.

AUGUSTI Y., RAYSSIGUIER Y., LARVOR P., DURLACH J., 1973. Carence en magnésium chez le rat et variations de certains paramètres protéiques sériques. C. R. Soc. Biol., 167, 1804-1808.

BATTIFORA H., 1971. Effects of magnesium deficiency on blood cells, 501-516. In : 1st International Symposium on Magnesium deficiency. J. Durlach editor, S. G. E. M. V. publisher, Vittel, France.

BERG B. N., 1965. Spontaneous nephrosis, with proteinuria, hyperglobulinemia, and hypercholesterolemie in the rat. Proc. Soc. Exp. Biol. Med., 119, 417-420.

BOIS P., GASCON A., BEAULNES A., 1963. Histamine-liberating effect of magnesium deficiency in the rat. Nature, 197, 501-502.

BRITTON N. M., STOKSTAD E. L. R., 1970. Aorta and other soft tissue calcification in the Mg deficient rat. J. Nutrition, 100, 1501-1505.

BUNCE G. E., REEVES P. G., OBA, T. S., SAUBERLICH H. E., 1963. Interference of the dietary protein level on the magnesium requirement. J. Nutr., 79, 220-226.

CANTIN M., 1973. Hyperaldosteronisme secondaire au cours de la carence en magnésium, 461-472. In : 1st International Symposium on Magnesium Deficiency, vol. 2 (communications), J. DURLACH editor, S. G. E. M. V. publisher, Vittel, France.

DE LA HUERGA J., ALVIN-DUBLIN M. S., DANIEL S., KUSHNER M. O., DYNIEWICZ Ph., POPPER M. D., 1956. Studies of serum mucoprotein (seromucoid). I.-A turbidimetric method. J. Lab. Clin. Med., 47, 403.

ELIN R. J., ARMSTRONG W. D., SINGER L., 1970. Adrenal gland factor in magnesium deficient rats. Proc. Soc. Exp. Biol. Med., 134, 542-547.

ELIN R. J. 1975. The effect of magnesium deficiency in mice on serum immunoglobulin concentrations and antibody plaque-forming cells. Proc. Soc. Exp. Biol. Med, 148, 620-624.

GINN H. E., CADE R., Mac CALLUM T., FREGLEY M., 1967. Aldosterone secretion in magnesium deficient rats. Endocrinology, 80, 969-997.

GORNALL A. G., BARDAWILL C. J., DAVID M. M., 1949. Determination of serum proteins by means of the biuret reaction. J. Biol. Chem., 177, 751.

GREENBERG D. M., LUCIA S. P., TUFTS, E. V., 1938. The effect of magnesium deprivation on renal function. Amer. J. Physiol., 121, 424-430.

JASMIN G. ,1963. Lymphœdème, hyperplasie ef tuméfaction du tissu lymphatique chez le rat soumis à une diète déficiente en magnésium. Rev. Can. Biol., 22, 383-390.

KO K., FELLERS F. X., CRAIG J. M., 1962. Observations on magnesium deficiency in the rat. Lab. Invest., 11, 294-305.

McCOY J. H., KENNEY M. A., 1975. Depressed immune response in the magnesium deficient raf. J. Nutr., 105, 791-797. 
MERLINO-SOLOUNIAS B., SCHWARTZ R., 1976. The effect of magnesium deficiency on serum aldosterone in rats fed two levels of sodium. Life Sciences, 17, 1211-1218.

MILLER E. R., ULLREY D. E., VINCENT B. H., HOEFER J. A., 1963. Deficiencies of magnesium and vitamin $\mathrm{D}$ and antibody production and hematology of the baby pig. J. Anim. Sci., 22,1127.

PECHERY CI., HENROTTE J. G., DURLACH J., DEPRAITIERE R., DE TRAVERSE P. M., 1971. Magnésium et infection, 633-635. In : 1st Infernotional Symposium on Magnesium deficiency. J. DURLACH editor, S. G. E. M. V. publisher, Vittel, France.

PROUVOST-DANON A., LARVOR P., RAYSSIGUIER Y., WYCZOLKOWSKA J., DURLACH J., 1975. Taux sérique d'anticorps réaginiques (IGE) chez la souris en carence magnésique. Rev. Franç. Allergol., 15, 147-150.

RAYSSIGUIER Y., LARVOR P., 1974. Influence du calcium alimentaire sur les calcifications rénales, la magnésémie et le magnésium osseux du rat carencé en magnésium. Ann. Biol. anim. Bioch. Biophys., 14, 145-156.

SCHWARTZ R., WANG F. L., WOODCOCK N. A., 1969. Effect of varying dietary protein-magnesium ratios on nitrogen utilization and magnesium retention in growing rats. J. Nutr., 97, 185-193.

SCHWARTZ R., WOODCOCK N. A., BLAKELY J. D., WANG F. L., KHAIRALLAH E. A., 1970 Effect of magnesium deficiency in growing rats on synthesis of liver proteins and serum albumin. J. Nutr., 100, 123-128. 